\title{
The Measurement Study on Impact Factors of Xinjing
}

\section{Agricultural GDP}

\author{
Fei Yin ${ }^{1}$, Chuanhui Zhang ${ }^{2}$, Qiang Jia ${ }^{3}$ \\ ${ }^{1}$ School of Economics and Management, Tarim University, Alar, 843300.
}

KEYWORDS: Xinjiang Agricultural Output Critical; Factors; Measurement Analysis

\begin{abstract}
In this paper, empirical analysis of the relevant factors from Xinjiang's agricultural output is conducted and used Eviews software from agricultural machinery power (MW), agricultural chemical fertilizer (tonnes), agriculture (person) practitioners, effective irrigation area (thousand ha) and food production (tons) of these factors to econometric analysis of factors affecting agricultural output in Xinjiang. In order to identify factors that affect agricultural output in Xinjiang and its relevances.
\end{abstract}

\section{The Problems}

Since the western development, Xinjiang, the country's total agricultural output value of agricultural output in the proportion of about 3\%, and the upward trend, which shows that the proportion of the country's total agricultural Xinjiang gradually increasing, which requires the State must take in Xinjiang do a good job of agriculture, the development of the country's total agricultural output value up about $3 \%$ of the region, which is conducive to the development of Xinjiang, but also conducive to China's agricultural development and the consolidation of the status. In this paper, a method of data analysis to find factors that affect agricultural output in Xinjiang and its relevance.

\section{The Establishment of the Model}

Factors affecting agricultural output are many, how to select the appropriate factors, data processing and analysis have a great impact [2], the purpose of this paper is the following from several factors which identify the impact of agricultural output in Xinjiang factors relevant extent, therefore, the paper selected agricultural machinery power (MW), agricultural chemical fertilizer (tonnes), agriculture (person) practitioners, effective irrigation area (000 ha) and food production (tons) these and other factors to study the effects on Xinjiang agricultural output.

So we set up the regression equation:

Including: Agricultural output value (million)

Agricultural machinery power (MW)

Of Chemical Fertilizers (tonnes) 
Agriculture (person) employees

To effectively irrigated area (000 ha)

To food production (tons)

Random error term

\section{The Practice Analysis}

Table 1. 1990--2014 Xinjiang agricultural output and Statistics of various factors

\begin{tabular}{|c|c|c|c|c|c|c|}
\hline Year & $\begin{array}{l}\text { Agricultu } \\
\text { re } \\
\text { (10Tho } \\
\text { usand) }\end{array}$ & $\begin{array}{l}\text { Agricultu } \\
\text { ral } \\
\text { machiner } \\
\text { y total } \\
\text { power } \\
\text { (MW) } \\
\end{array}$ & $\begin{array}{l}\text { Chemical } \\
\text { Fertilizer } \\
\text { s (tonnes) }\end{array}$ & $\begin{array}{l}\text { Agricultu } \\
\text { ral } \\
\text { workers } \\
\text { (people) }\end{array}$ & $\begin{array}{l}\text { Effective } \\
\text { irrigation } \\
\text { area (000 } \\
\text { ha) }\end{array}$ & $\begin{array}{c}\text { Food } \\
\text { productio } \\
\text { n (tons) }\end{array}$ \\
\hline 1995 & 2890000 & 599.8165 & 62.20183 & 2866972 & 2550.459 & 6699083 \\
\hline 1996 & 2796437 & 585. 0298 & 64. 69731 & 2668586 & 2378. 457 & 6848925 \\
\hline 1997 & 3068444 & 601.2969 & 68. 77123 & 2748633 & 2388.282 & 6811470 \\
\hline 1998 & 3086634 & 614.0601 & 68. 20235 & 2740045 & 2377.226 & 6665664 \\
\hline 1999 & 2604454 & 622.1269 & 59.83694 & 2728681 & 2341.685 & 6407510 \\
\hline 2000 & 2740496 & 652.5525 & 60.20054 & 2691542 & 2352. 002 & 6146232 \\
\hline 2001 & 2534959 & 641.7315 & 60.53248 & 2656017 & 2280.396 & 5784377 \\
\hline 2002 & 2368874 & 601.7904 & 54. 89172 & 2435942 & 1988. 539 & 5703205 \\
\hline 2003 & 3118789 & 629.1195 & 58. 61618 & 2473972 & & 5178430 \\
\hline 2004 & 3236193 & 658.4844 & 62.33577 & 2482748 & 1952. 165 & 5206356 \\
\hline 2005 & 3382322 & 636.3545 & 61.1923 & 2292838 & 1818. 91 & 4979453 \\
\hline 2006 & 3396348 & 633.0424 & 63. 33072 & 2195394 & 1765.847 & 4777339 \\
\hline 2007 & 3661988 & 609.0209 & 62.80244 & 2171705 & 1654.646 & 4139909 \\
\hline 2008 & 3535758 & 620.2231 & 67. 13522 & 2102022 & 1610.749 & 4098450 \\
\hline 2009 & 3765459 & 629. 9296 & 65. 49414 & 2039579 & 1540.223 & 4827207 \\
\hline 2010 & 4860659 & 580.2502 & 59. 16526 & 1642577 & 1313.779 & 4060375 \\
\hline 2011 & 4581194 & 572.4334 & 58. 52142 & 1600752 & 1237.645 & 3901959 \\
\hline 2012 & 4604520 & 541.2441 & 52. 9726 & 1482591 & 1107.586 & 3499435 \\
\hline 2013 & 6730280 & 574.1465 & 53. 87162 & 1342275 & 1168. 319 & 3607403 \\
\hline 2014 & 6667318 & 568. 1703 & 57.58061 & 1251844 & 1180. 302 & 3379355 \\
\hline
\end{tabular}

For the time series we must first examine its smoothness, with EG two-step method to examine whether there is a cointegration relationship between them. First, by using the ADF test, stability test of each sequence. 


\section{Augmented Dickey-Fuller Unit Root Test on LNY}

Null Hypothesis: LNY has a unit root

Exogenous: Constant

Lag Length: 0 (Automatic based on SIC, MAXLAG=4)

\begin{tabular}{lccc}
\hline \hline & & t-Statistic & Prob. $^{*}$ \\
\hline \hline Augmented Dickey-Fuller test statistic & 0.234414 & 0.9674 \\
\hline Test critical values: & 1\% level & -3.831511 & \\
& $5 \%$ level & -3.029970 & \\
& $10 \%$ level & -2.655194 & \\
\hline \hline
\end{tabular}

*MacKinnon (1996) one-sided p-values.

Warning: Probabilities and critical values calculated for 20 observations and may not be accurate for a sample size of 19

\section{Augmented Dickey-Fuller Test Equation}

Dependent Variable: D(LNY)

Method: Least Squares

Date: 03/25/16 Time: 12:35

Figure 1. ADF analysis chart Xinjiang agricultural output lny sequence

From the test results of FIG. 1 view, at 1\%, 5\%, 10\% three significant level, the critical value of the unit root tests were $-3.831511,-3.02997,-2.655194=0.234414$ is greater than its corresponding critical value and thus can not reject $\mathrm{H} 0$, show that agricultural GDP Xinjiang y sequence is a unit root, the non-stationary series.

\begin{tabular}{|c|c|c|}
\hline \multicolumn{3}{|c|}{ Augmented Dickey-Fuller Unit Root Test on D(LNY) } \\
\hline \multicolumn{3}{|c|}{$\begin{array}{l}\text { Null Hypothesis: } D(L N Y) \text { has a unit root } \\
\text { Exogenous: Constant } \\
\text { Lag Length: } 0 \text { (Automatic based on SIC, MAXLAG=4) }\end{array}$} \\
\hline & t-Statistic & Prob.* \\
\hline Augmented Dickey-Fuller test statistic & -4.939839 & 0.0011 \\
\hline $\begin{array}{lc}\text { Test critical values: } & 1 \% \text { level } \\
& 5 \% \text { level } \\
& 10 \% \text { level }\end{array}$ & $\begin{array}{l}-3.857386 \\
-3.040391 \\
-2.660551\end{array}$ & \\
\hline
\end{tabular}

*MacKinnon (1996) one-sided p-values.

Warning: Probabilities and critical values calculated for 20 observations and may not be accurate for a sample size of 18

\section{Augmented Dickey-Fuller Test Equation \\ Dependent Variable: D(LNY,2) \\ Method: Least Squares \\ Date: $03 / 25 / 16$ Time: $12: 37$}

Figure 2. The difference sequence ADF analysis chart of Xinjiang agricultural output lny

From the test results of FIG. 2 view, at 1\%, 5\%, 10\% three significant level, the critical value of the unit root tests were $-3.857386,-3.040391,-2.660551,-4.939839=$ smaller than its corresponding critical values to reject H0, show that agricultural GDP of Xinjiang y first-order difference sequence there is no unit root for smooth series. 
We can use the same method, testable $\ln X_{1}, \ln X_{2}, \ln X_{3}, \quad \ln X_{4}, \quad \ln X_{5}$ the case of $\ln X_{1}, \ln X_{2}, \ln X_{3}, \quad \ln X_{4}, \quad \ln X_{5}$ are integrated of order one sequence.

In order to analyze whether the cointegration relationship between GDP and agricultural production in the Xinjiang $\ln X_{1}, \ln X_{2}, \ln X_{3}, \quad \ln X_{4}, \ln X_{5}$, we do first return to six variables, then the regression residuals stability.

\begin{tabular}{|c|c|c|c|c|}
\hline \multicolumn{5}{|c|}{$\begin{array}{l}\text { Dependent Variable: LNY } \\
\text { Method: Least Squares } \\
\text { Date: 03/25/16 Time: } 13: 17 \\
\text { Sample: } 19952014 \\
\text { Included observations: } 20\end{array}$} \\
\hline Variable & Coefficient & Std. Error & t-Statistic & Prob. \\
\hline C & 33.18338 & 5.557732 & 5.970670 & 0.0000 \\
\hline LNX1 & 0.236628 & 0.604476 & 0.391460 & 0.7014 \\
\hline LNX2 & 0.905595 & 0.325507 & 2.782103 & 0.0147 \\
\hline LNX3 & -1.875755 & 0.354553 & -5.290474 & 0.0001 \\
\hline LNX4 & 0.637453 & 0.429452 & 1.484341 & 0.1599 \\
\hline LNX5 & -0.049115 & 0.358828 & -0.136877 & 0.8931 \\
\hline R-squared & 0.940010 & \multicolumn{2}{|c|}{ Mean dependent var } & 15.07400 \\
\hline Adjusted R-squared & 0.918586 & \multicolumn{2}{|c|}{ S.D. dependent var } & 0.294736 \\
\hline S.E. of regression & 0.084098 & \multicolumn{2}{|c|}{ Akaike info criterion } & -1.870353 \\
\hline Sum squared resid & 0.099014 & \multicolumn{2}{|c|}{ Schwarz criterion } & -1.571634 \\
\hline Log likelihood & 24.70353 & \multicolumn{2}{|c|}{ Hannan-Quinn criter. } & -1.812040 \\
\hline F-statistic & 43.87482 & \multirow{2}{*}{\multicolumn{2}{|c|}{ Durbin-Watson stat }} & 2.072430 \\
\hline Prob(F-statistic) & 0.000000 & & & \\
\hline
\end{tabular}

Figure 3. Regression results

Figure 3 can be drawn from the estimated regression model is:

Lny $=33.18338+0.236628 \ln x 1+0.905595 \ln x 2-1.875755 \ln x 3+0.637453 \ln x 4-0.0491151$ $\mathrm{nx} 5+\mathrm{et}$

From the test results in FIG. 4 view, at 1\%, 5\%, 10\% three significant level, the critical value of the unit root tests were $-2.692358,-1.960171,-1.607051,-4.930246=$ smaller than its corresponding critical value indicates that there is no unit root residuals, in order to smooth the number of columns. Therefore, there is cointegration, indicating the presence of long-term equilibrium relationship $\ln , \ln , \ln , \ln , \ln$ and $\ln y$ between lny and $\ln , \ln , \ln , \ln , \ln$. Although the long term model is balanced, but the imbalance may occur in the short term, through error correction model $\mathrm{Y}$ and $\mathrm{ln}, \mathrm{ln}, \mathrm{ln}$, ln, short-term and long-term changes $\ln$ linked. Structure error correction model are as follows:

$$
\triangle \ln \mathrm{y}=\mathrm{a}+\mathrm{b} 1 \Delta \ln \mathrm{X} 1+\mathrm{b} 2 \Delta \ln \mathrm{X} 2+\mathrm{b} 3 \Delta \ln \mathrm{X} 3+\mathrm{b} 4 \Delta \ln \mathrm{X} 4+\mathrm{b} 5 \Delta \ln \mathrm{X} 5+\varepsilon \mathrm{t}
$$




\begin{tabular}{|c|c|c|c|c|}
\hline Variable & Coefficient & Std. Error & t-Statistic & Prob. \\
\hline C & -0.048045 & 0.036727 & -1.308157 & 0.2153 \\
\hline DLNX1 & 2.174984 & 1.046568 & 2.078207 & 0.0598 \\
\hline DLNX2 & 0.838710 & 0.329860 & 2.542626 & 0.0258 \\
\hline DLNX3 & -2.309384 & 0.368801 & -6.261876 & 0.0000 \\
\hline DLNX4 & 0.295507 & 0.752455 & 0.392723 & 0.7014 \\
\hline DLNX5 & -0.483144 & 0.257620 & -1.875408 & 0.0853 \\
\hline $\mathrm{ET}(-1)$ & -1.107792 & 0.243123 & -4.556515 & 0.0007 \\
\hline R-squared & 0.836162 & \multicolumn{2}{|c|}{ Mean dependent var } & 0.043998 \\
\hline Adjusted R-squared & 0.754243 & \multicolumn{2}{|c|}{ S.D. dependent var } & 0.132871 \\
\hline S.E. of regression & 0.065869 & \multicolumn{2}{|c|}{ Akaike info criterion } & -2.324973 \\
\hline Sum squared resid & 0.052065 & \multicolumn{2}{|c|}{ Schwarz criterion } & -1.977022 \\
\hline Log likelihood & 29.08724 & \multirow{2}{*}{\multicolumn{2}{|c|}{$\begin{array}{l}\text { Hannan-Quinn criter. } \\
\text { Durbin-Watson stat }\end{array}$}} & -2.266086 \\
\hline F-statistic & 10.20717 & & & 1.937618 \\
\hline Prob(F-statistic) & 0.000400 & & & \\
\hline
\end{tabular}

$\triangle$ lny $=-0.0488+2.1750 \quad \Delta \ln \mathrm{X} 1+0.8387 \quad \Delta \ln \mathrm{X} 2-2.3094 \Delta \ln \mathrm{X} 3+0.2955 \Delta$ $\ln \mathrm{X} 4-0.4831 \Delta \ln \mathrm{X} 5-1.1078$

$(-1.8754)(-4.5565)$
$\mathrm{t}=(-1.3082)$
(2.0782)
(2.5426)
$(-6.2619)$
$(0.3917)$

$R^{2}=0.8362$

DW=1.9376

From the above equation model shows that, on a total power of agricultural machinery in Xinjiang every 1\% increase in the current agricultural output in Xinjiang will increase 2.1750 percent; on an agricultural chemical fertilizer every $1 \%$ increase in Xinjiang, Xinjiang period the agricultural output will increase 0.8387 percent; agricultural workers on a $1 \%$ rise in Xinjiang, the current reduction in agricultural output in Xinjiang is 2.3094\%; on an effective irrigation area of Xinjiang every 1\% increase in the present Xinjiang agricultural output will increase 0.2955 percent; food production on a $1 \%$ rise in Xinjiang, the current reduction in agricultural output in Xinjiang is $-0.4831 \%$.

\section{Relevant Suggestions}

Based on the final results of the model can be found in factors which affect agricultural output value of Xinjiang's total power of agricultural machinery is the most significant and second factors more significant is the number of agricultural workers, and finally the application amount of agricultural fertilizers. According to the existing problems, it can give the following advice.

The results can be seen in agricultural workers, rural surplus labor exists portion, therefore, need to be appropriate to transfer these surplus labor out, this is the rational use of human resources on the one hand but also to reduce the pressure on agriculture, rural areas and farmers, this will not only achieve a stable development of the 
agricultural output has also realized the rational use of human resources, in favor of resources in the whole region of the rational allocation.

Agricultural Mechanization in Xinjiang agricultural output the most significant, and therefore we must increase investment in agricultural mechanization, modern society is a science and technology, mechanization of society, the use of mechanized power can significantly increase agricultural output, optimize and increase agricultural mechanization, and efforts to improve the level of mechanization of agricultural production in Xinjiang.

The application of fertilizers on agricultural output in Xinjiang more significant, therefore, to a reasonable application of fertilizer, including fertilizer procurement, transportation as well as preservation, agricultural production should be appropriate to increase the amount of fertilizer applied, in order to increase Xinjiang agricultural output, an appropriate increase in a certain amount of chemical fertilizer could increase agricultural output in Xinjiang, but cannot exceed a certain limit, otherwise prone to unnecessary waste and pollution.

In summary, to raise the overall level of development of Xinjiang's agricultural output, we must increase agricultural mechanization investment, transfer of rural surplus labor force, a reasonable application of chemical fertilizer, so you can drive the development of other related industries, the consolidation of Xinjiang Agricultural on the basis of status and improving their life satisfaction.

\section{Acknowledgements}

Proj: Ministry of Education, "New Century Talents Support Program" ,

Proj No, NCET-13-0925.

Proj: the Xinjiang Production and Construction Corps Excellence Project; Corps Social Science Fund Project,

Proj No. 13QN14.

\section{REFERENCE:}

[1] Region of Xinjiang Bureau of Statistics, National Bureau of Xinjiang Statistical Yearbook [M]. Beijing: China Statistics Press, 2013.

[2] Zheng Tingting. Factors Agricultural Output Analysis and Model Test [J]. Managers. 2010 (11).

[3] Zhang Jianhong. Agricultural Industrial Structure Adjustment Impact on Farmers' Income Empirical Analysis [J]. Economic Perspectives (Under). 2009

[4] Li Guozhang, Zhou Qi. Factors Affecting China's Agricultural Output Value Of [J]. Statistics and Decision 2007 (22)

[5] Feng Hongxing, Pu Chunling, Liu Xinping. Agricultural Industrial Structure Adjustment [J]. Modern Agricultural Sciences. 2008

[6] Zhang Zhenhua, Liu Weihua. Promoting Agricultural Industrialization Thought Process [J]. Reclamation Economy .1998 (03)

[7] Baidu Encyclopedia and Baidu Library www.Baidu.Com, Wenku.Baidu.Com 
[8] Zeng Yu, Liu Jianfu. On The Issues of Sustainable Agricultural Development in Xinjiang [J]

[9] Li Zinai, Pan Wenqing. Edited Econometrics Beijing: Higher Education Press, 2010.3.

[10] Jia Jun Ping, He Xiaoqun, Jing Yongjin. Statistical Editor (Fourth Edition) Beijing: Renmin University of China University Press, 2009. 